УДК 811.161.2’243:37.016

DOI 10.11603/me.2414-5998.2020.1.10994

L. T. Nazarevych

ORCID https://orcid.org/0000-0002-0566-9200

ResearcherID AAC-2202-2020

N. R. Denysiuk

ORCID https://orcid.org/0000-0001-8197-2183

ResearcherID AAD-4235-2020

N. I. Havdyda

ORCID https://orcid.org/0000-0002-1444-1902

ResearcherID AAC-4003-2020

Ternopil Ivan Puliui National Technical University

\title{
THEORETICAL AND PRACTICAL APPROACHES TO TEACHING UKRAINIAN AS A FOREIGN LANGUAGE AT TNTU
}

\section{Л. Т. Назаревич, Н. Р. Денисюк, Н. І. Гавдида \\ Тернопільський національний технічний університет імені Івана Пулюя \\ ТЕОРЕТИКО-ПРАКТИЧНІ ПІДХОДИ ДО ВИКЛАДАННЯ УКРАЇНСЬКОЇ МОВИ ЯК ІНОЗЕМНОЇ В ТЕРНОПІЛЬСЬКОМУ НАЦІОНАЛЬНОМУ ТЕХНІЧНОМУ УНІВЕРСИТЕТІ ІМЕНІ ІВАНА ПУЛЮЯ}

\begin{abstract}
The methodology of teaching Ukrainian as a foreign language is considered in the article; the issues of the language adaptation of foreign students are emphasized. The ability to communicate not only in the educational setting but also in the extracurricular time is stated as the objective of studying the educational course "Ukrainian as a foreign language". Traditional and innovative approaches that simulate real life situations, offer problems for shared resolutions, enhance students' creative ability, mobilize their attention, and teach them how to develop speech constructs quickly are analyzed. The focus is on a person-centered approach to the classroom, in particular, the game approach as a casual way of submitting starting material. Communicative activity, its main components, and intercultural competence issues were significantly analyzed. The authors share experience in developing tutorials and test assignments; an easy-to-use and informative distance course in the Atutor system; additional training materials in the form of tables, diagrams, exercises, crossword puzzles posted on the social network Facebook. This course allows monitoring the level of theoretical knowledge and practical skills of students-foreigners in educational-training and game forms. The role of identification as a basic principle of eidetics is analyzed, namely: multimedia presentations that allow both visual and auditory perception of information; qualitatively designed slides; study cards; photos, etc. Examples of the application of different methods of eidetics are given: a chain method, a method of combining a verbal apparatus with the imagination, a method of reconciling fantasy and imagination with the ability to express clearly own thoughts, the method of phonetic associations, work on eidos-abstract, etc. The authors emphasize the benefits of training in an atmosphere of psychological safety and comfort.
\end{abstract}

Key words: communication; game; visualization; imagination; association; method.

Анотація. У статті йдеться про методику навчання української мови як іноземної та мовну адаптацію студентів-іноземців. Акцентовано на основній меті вивчення цієї дисципліни, а саме: вмінні спілкуватися не лише в навчальному, а й позанавчальному середовищі. Розглянуто традиційні та новаторські підходи, які моделюють реальні життєві ситуації, пропонують проблеми для спільного розв’язання, активізують творчі здібності студентів, мобілізують їхню увагу, навчають їх швидко будувати мовленнєві конструкції, знаходячи відповідні засоби для вираження змісту. Зосереджено увагу на особистісно-орієнтованому підході на заняттях, зокрема, виокремлено ігровий підхід як невимушений спосіб подачі начального матеріалу. Цілісно проаналізовано комунікативну діяльність та ї̈ головні компоненти, порушено питання інтеркультурної компетенції. Автори діляться досвідом розробки навчальних посібників і тестових завдань; зручного в користуванні та інформативного дистанційного курсу в системі Atutor, який слугує організацією всього процесу навчання; також додаткових навчальних матеріалів у формі таблиць, схем, вправ, кросвордів, розміщених у соціальній мережі «Фейсбук». Зазначено, що такий підхід дозволяє здійснювати контроль рівня теоретичних знань, практичних умінь і навичок студентів-іноземців у навчально-тренувальній та ігровій формах. Проаналізовано роль унаочнення як основного принципу ейдетики, а саме: мультимедійні презентації, що уможливлюють одночасно зорове і слухове сприйняття інформації, якісно розроблені слайди, навчальні картки, світлини. Наведено приклади застосування різних методів ейдетики: ланцюжковий, метод поєднання вербального апарату з роботою уяви, метод узгодження фантазії та уяви з умінням чітко висловлювати

(C) L. T. Nazarevych, N. R. Denysiuk, N. I. Havdyda 
власні думки, метод фонетичних асоціацій, робота над ейдос-конспектом тощо. Автори наголошують на перевазі навчання в атмосфері психологічної безпеки та комфорту.

Ключові слова: комунікація; гра; візуалізація; уява; асоціація; метод.

Introduction. Traditionally, from the educative point of view, the human automatically acquires the mother tongue from the early childhood, and then (in educational establishments) masters it by writing and grammar. Foreigners begin to learn Ukrainian from an "absolute zero" level, and the use of a mediator language (English or French) at this stage is very important. By means of such mediator languages, the teacher can explain to students the peculiarities of language phenomena and processes. Every year, the number of foreign citizens who come to study at universities in Ukraine increases, so the acquisition of the Ukrainian language is an integral part of the educational process.

Nowadays, interactive teaching methods are at the forefront of simulating real-life situations for solving mutual problems. The methods include role-playing games that activate students' creative abilities, mobilize their attention, and teach them how to develop their language quickly. Therefore, they help find the right tools for expressing the content. After all, the challenge of the methodology of teaching Ukrainian as a foreign language is communication, that is, the ability to communicate not only in the educational setting but also in the extracurricular time.

Nowadays, due to political, social, and educational processes, there is a great interest in learning Ukrainian. M. Ardelian, L. Bay, M. Vynnyk, H. Kytaihorodska, O. Palinska, V. Vinnytska, O. Haida, T. Yefimov, I. Pidhorodetska, S. Sokol, G. Tohtar, O. Trostynska, H. Shvets, and others studied the problem of teaching foreigners of the Ukrainian language. Thus, according to O. Palchykova, teaching Ukrainian as a foreign language "requires improvement of traditional approaches in linguistics, aimed primarily at the development of linguistic, speech and grammatical competences. A crosscultural component requires mastering cultural experience: experience of tradition, habits, behavioral norms, and peculiarities of the outlook of foreign students for effective and productive learning of the Ukrainian language” [10]. V. Makovska noted, "The problem of teaching a foreign language also touches upon other aspects of learning, one of them being the issue of intercultural competence. Unfortunately, this very popular discipline in the West passes by the attention of Ukrainian methodologists: among the principles, tasks and goals, this discourse is not mentioned. Although, at a foreign language lesson, due to its content, in particular texts and other nonverbal information, we learn new information and express our own thoughts. Both parties involved in the process of learning a foreign language are in an intercultural situation" [5].

The aim. As the technique of teaching Ukrainian as a foreign language is at the stage of formation and therefore insignificantly studied, the objectives of the article are:

- to analyze the experience gained by the Ukrainian and Foreign Languages Department of TNTU in the field of teaching Ukrainian as a foreign language;

- to highlight modern and innovative approaches to the study of this discipline.

The course is designed to realize the modern academic goals of language education, including the development of the communicative competence of speakers in its national dimension, the preservation and enhancement of the linguistic and cultural potential of Ukraine, the promotion of linguistic and cultural tolerance, the implementation of principles of civic education and democratic society. The methodology of teaching Ukrainian as a foreign language is under the study.

Methods. The general scientific methods, in particular descriptive, empirical, analysis, synthesis, and comparison are considered in this article. The comtarative method is applied to analyze the effect of different teaching and training techniques on remembering vocabulary and developing communicative skills.

Results. Since 2012, the scientific and pedagogical staff of the Ukrainian and Foreign Languages Department of TNTU has developed a series of training materials on the course "Ukrainian as a Foreign Language", namely, "Test assignments in Ukrainian as a Foreign Language", "Grammar of Ukrainian as a Foreign Language", "Methodical Recommendations, Tasks and Examples of Responses to the State Exam in the course "Ukrainian as a Foreign Language", the textbook "Practical Course of the Ukrainian Language. Professional and Business Language (for foreign students who study in Ukrainian)", "Ukrainian language. Practical course for foreigners", "Ukrainian language for foreigners. Workshop (Levels B1 - B2) [9]. 
In addition, to organize the entire learning process and facilitate the rapid and qualitative assimilation of educational material, a distance course is developed in the Atutor system. It is easy to use and informative. Here you can find all educational and theoretical materials, presentations (they can be viewed through file share), and various test assignments in electronic form. An accessible presentation helps acquire the necessary knowledge, systematize and summarize previously studied material; it allows checking student's educational achievements, analyzing test results, identifying common mistakes and ways of their elimination. The sequence of the material presentation is optimal for its acquisition.

The audio podcasts and visual materials posted on Facebook (https://www.facebook.com/ukrainian.for. foreigners/) can be used when learning Ukrainian as a foreign language. As the reading, listening, and repeating activities are considered the most effective in learning a language, the teachers have developed a number of audio podcasts to improve students' knowledge, in particular pronunciation. Audio podcasts to the book "The Ukrainian Language for Foreigners" by L. T. Nazarevych and N. I. Havdyda are available on the Sound Cloud service at https://soundcloud.com/ tags/learn\%20ukraine. The method involves several steps: 1) listening at a regular pace; 2) slow-motion listening and simultaneous reading of a text from the textbook, with reproduction of the speaker's intonation; 3) listening and reading at a rapid pace, understanding what is heard and read, answering questions, retelling. The advantage of this method is the accessibility and ability to download audio podcasts for offline listening without internet access.

In recent years, there has been a tendency to digitilize. We keep up with the times, so we invite international students to spend time on social networks for the benefit of reading grammar tables and pictures illustrating a particular concept or phenomenon. All of the materials provided at the link: https:// www.facebook.com/ukrainian.for.foreigners/ help students use the learning materials via mobile devices (m-learning) outside the classroom.

The methodological training materials serve as a bridge for active and interactive learning, provide feedback between the teacher and students (explanations, verification of completed tasks and work on mistakes), and facilitate the exchange of information between all participants of the learning process.

One of the challenges of the modern methodology of teaching Ukrainian as a foreign language is the development of tools to control the level of students' knowledge. A testing exercises system that provides a material visualization is considered the most effective form of monitoring a foreign language competence. This kind of work requires intense mental work of students, which is realized through the psychological processes of analysis, synthesis, identification, comparison, etc.

That is why the teachers of the Ukrainian and Foreign Languages Department pay considerable attention to the preparation of test tasks in Ukrainian as a foreign language, which are available in the distance learning system of the Ternopil Ivan Puliui National Technical University. The educational test tasks are aimed at testing the level of theoretical knowledge and practical skills of foreign students of full-time education and students of the preparatory department. The Kahoot Quiz is a unique opportunity to test knowledge in a game form. This platform helps the teacher quickly find out how students have learned new material. The advantage is that you only need to have a smartphone. High-speed 3G and 4G mobile coverage lets you connect to the kahoot.it server. To start the quiz, the teacher loads pre-designed questions, and the student enters a unique server-generated number to join the quiz. The quiz comes in an interactive, playful form. The assessment takes into account not only the correct answer, but also the time spent by students while answering [8].

In recent years, there is a great interest in eidetics as a science, because it offers the teaching ways to develop imaginative memory, facilitate quick and conscious memorization of new material, and turn the learning process into a fun game. The students are trained in an atmosphere of psychological safety and comfort, which improves their relationship with the "alien" environment, develops new skills, reveals their own behavioral emotional and thinking stereotypes. The scientific papers of the founders of the Eidetics School "How to memorize foreign words" (I. Matiuhin) [6], "The method of non-verbal associations" [2], "Rapid pedagogical help - learning to memorize” [3], "Meet your memory" [1] (Y. Antoshchuk) will help each teacher to find their own way of teaching.

V. Sukhomlynskyi, M. Hankina, Y. Antoshchuk, H. Kytaihorodska, O. Palinska, H. Shvets, and others highlighted practical and game-based approaches to learning Ukrainian as a foreign language. We believe that not every game is appropriate. However, the introduction of a game as a way of developing practical skills, consolidation or systematization of educational 
material makes it possible to diversify teaching, creates a favorable psycho-emotional climate, an atmosphere of confidence, and healthy competition.

The role of traditional principles and methods of teaching is indisputable. But we argue that the innovative ones, in particular presentations, case studies, critical thinking, quizzes, blitz surveys, brainstorming, imaginative associations, mobility, information distribution according to the characteristics of each individual, fantasizing and so on should be implemented as well. According to Y. Antoshchuk, such approaches intensify the desire to learn, develop attention, and form the ability to create original ideas [1].

We agree that the basic principle of eidetics is visualization, without which learning new material is impossible. Moreover, the task of eidetics is simply to organize all possible resources of human memory for the use of acquired knowledge in life. S. Voloshynov emphasizes: "In the study of a certain subject, visualization of learning combines two sides of cognition - the sensitive and the thinking ones, and contributes to the disclosure of the external signs and properties of this subject" [4]. To achieve this goal, the following methods of eidetics shoul be applied: chain, acroverbal, pictographic, phonetic associations, method of places (based on visual associations), non-verbal associations, paradoxical verbal transformations, enlarged structuring of educational material (involving the use of textbooks). In this case, visualization is realized by creating multimedia presentations while learning conversational topics and mastering grammar. The advantage of the latest technologies is that they allow both visual and auditory perception of information. When working with well-designed slides, it is easier for students to establish cause-and-effect relationships between micro-topics, to perceive new information, as it is possible to repeat the sentence after the teacher and see a text-related diagram, photo, and map. 'Screen Communication' visualizes what is heard, and consolidates the relevant association.

During the lessons of Ukrainian as a foreign language, we also practice such an approach as an eidos-synopsis - reflections that arise in the process of reading any text. For example, this kind of work is effective: the teacher dictates 10 words or phrases from the text "Ivan Puliui - an inventor of X-rays" [9], and students remember them: electrical engineer, translator, incandescent lamp, appliance, anticathode, invention, patent, AC, cathode radiation, X-radiation.
Each pause between words should be filled with music. After that, students put the number 1 and write down in the notebook what they have memorized. The next stage - the group looks at 10 words written on the board: X-ray, mechanism, negatively charged parts, molecule, atom, Enstein, epochal, deny, Nobel Prize, deceit - and memorize them. The teacher closes the words, and the students under the number 2 write down what they have memorized. Then, it is necessary to calculate the words. If there are more words under the number 1, then the person is an auditory learner (that is, hearing is his or her leading analyzer), and if - under the number 2 , we can conclude that for a group of these persons the leading analyzer is vision, that is, they are visuals. The method of combining the verbal apparatus with the imaginary activity activates and energizes the imagination. Students should verbalize as many nouns as possible in 60 seconds. After that, they should name the objects that pop up in their imagination. The teacher's job is to ask clarifying questions to hear a complete story about the subject.

Ihor Matyugin, Doctor of Pedagogical Sciences, believes that Cicero's method or the place method will help to remember information [6]. We encourage students to stick multicolored cards at home with words or punctuation that need to be learned. So, for better visualization, each part of the language should be written on a different color card. For example, nouns are in green, verbs are in red, numerals are in blue, pronouns are in white, adjectives are in pink, conjunctions are in purple.

The place method is based on visual associations: you need to clearly visualize the object you want to remember and combine its image with the image of a particular place. Its effectiveness is observed at the initial stage of training. For example, stick the names of vegetables, fruits and other products on the refrigerator. The method of phonetic associations is that the word of a foreign language should be matched with a consonant or phrase from the native language or from already known foreign languages.

In the course of the educational game, learning new words and language constructions is easy. Moreover, students, feeling the taste of the game, expect it as an opportunity for self-improvement. An important advantage is that the playing in micro groups increases students' communication skills and curiosity.

Conclusions and Prospects for Research. We did not set out to reveal the essence of all teaching methods, including eidetics, the use of which facilitates easy memorization of new information. We argue that the 
implementation of the principles and methodology discussed in the article will contribute to the successful adaptation of foreign students at Ukrainian universities. We believe that the combination of traditional and non-traditional methods of teaching Ukrainian as a

\section{List of literature}

1. Антощук $€$. В. Знайомтесь, ваша пам’ять: швидка педагогічна допомога від Української школи ейдетики / Є. В. Антощук. - К. : Вирій, 2009. - 192 с.

2. Антощук $€$. В. Метод невербальних асоціацій / Є. В. Антощук // Завуч. - 2007. - № 30. - С. 13-14.

3. Антощук $€$. В. Швидка педагогічна допомога / Є. В. Антощук // Початкова освіта. - 2000. - № 3 (51). - С. 3.

4. Волошинов С. А. Реалізація дидактичного принципу наочності в алгоритмічній підготовці студентів засобами інформаційно-комунікативного педагогічного середовища / С. А Волошинов // Інформаційні технології в освіті. - 2011. - Вип. 10. - С. 173-182. - URL : http://ite. kspu.edu/webfm_send/231.

5. Маковська В. Викладання української мови іноземцям: тяглість старої традиції / В. Маковська // Теорія і практика викладання української мови як іноземної : зб. наук. праць. Вип. 4. - Львів, 2009. - С. 39-44.

6. Матюгин И. Ю. Методы развития памяти, образного мышления, воображения / И. Ю. Матюгин, И. К. Рыбникова. - М. : Эйдос, 1996. - 60 с.

7. Назаревич Л. Т. Використання інформаційної технології аудіоподкастів для вивчення української мови як іноземної / Л. Т. Назаревич, О. Б. Назаревич // Iн-

\section{References}

1. Antoshchuk, Ye.V. (2009). Znaiomtes, vasha pamiat: shvydka pedahohichna dopomoha vid ukrainskoi shkoly aidetyky [Get to know your memory: Emergency pedagogical assistance from the Ukrainian school of Eidetics]. Kyiv: Vyrii [in Ukrainian].

2. Antoshchuk, Ye.V. (2007). Metod neverbalnykh asotsiatsii [Non-verbal association method]. Zavuch - Deputy Head, 30, 13-14 [in Ukrainian].

3. Antoshchuk, Ye.V. (2000). Shvydka pedahohichna dopomoha [Rapid pedagogical assistance]. Pochatkova osvita - Primary Education, 3 (51), 3 [in Ukrainian].

4. Voloshynov, S.A. (2011). Realizatsiia dydaktychnoho pryntsypu naochnosti $\mathrm{v}$ alhorytmichnii pidhotovtsi studentiv zasobamu informatsiyno-komunikatyvnoho pedahohichnoho seredovyshcha [Implementation of the didactic principle of visualization in algorithmic preparation of students by means of the information-communicative pedagogical environment]. Informatsiini tekhnolohii $\mathrm{v}$ osviti - Information Technology in Education, 173-182 [in Ukrainian].

5. Makovska, V. (2009). Vykladannia ukrainskoi movy inozemtsiam: tiahlist staroi tradytsii [Teaching Ukrainian foreign language in higher educational establishments can produce high results. The topic under discussion requires further scientific studies, which are intended to solve as soon as possible the main problems in the methodology of teaching the Ukrainian language.

формаційні моделі, системи та технології : матеріали V наук.-техн. конф. - Тернопіль : ТНТУ, 2018. - C. 113. - URL : http://elartu.tntu.edu.ua/bitstream/lib/23827/2/VSTC-IMST_2018_Nazarevych_O-Using_information_ technology_113.pdf.

8. Назаревич Л. Т. Інноваційні підходи до вивчення української мови як іноземної за допомогою інтернеттехнологій / Л. Т. Назаревич, О. Б. Назаревич // Актуальні питання організації навчання іноземних студентів в Україні : матеріали IV Міжнар. наук.-метод. конф. (Тернопіль, 2-4 травня 2018 р.). - Тернопіль : ТНТУ, 2018. C. 76-78. - http://elartu.tntu.edu.ua/bitstream/lib/25106/23/ Zbirnyk_actual_problem_2018_v2.pdf\#page=76.

9. Назаревич Л. Т. Українська мова для іноземців. Практикум (Рівні В1-В2) : підручник / Л. Т. Назаревич, Н. І. Гавдида. - 2-ге вид., змінене й доповнене, ілюстроване. - Тернопіль : ФОП Паляниця В. А., 2017. - 212 с. URL : http://elartu.tntu.edu.ua/handle/lib/26894.

10. Пальчикова О. О. Проблеми навчання української мови в іншомовній аудиторії / О. О. Пальчикова. - URL : http://seanewdim.com/uploads/3/2/1/3/3213611/ palchickova_a.a._problems_of_teaching_ukrainian_in_a_ foreign_language_audience.pdf.

to foreigners: the gravity of an old tradition]. Theory and Practice of Teaching Ukrainian as a Foreign Language: Coll. of Scientific Works, 4. Lviv [in Ukrainian].

6. Matyugin, I.Yu., \& Pybnikova, I.K. (1996). Metody razvitiya pamyati, obraznogo myshlenya, voobrazhenya [Methods for the development of memory, imaginative thinking, imagination]. Moscow: Eidos [in Russian].

7. Nazarevych, L.T., \& Nazarevych, O.B. (2018). Vykorystannia informatsiynoi tekhnolohii audiopodkastiv dlia vyvchennia ukrainskoi movy yak inozemnoi [Use of audio podcast information technology to study Ukrainian as a foreign language]. Proceedings of the Scientific and Technical Conference "Information Models, Systems and Technologies”. Ternopil: TNTU [in Ukrainian].

8. Nazarevych, L.T., \& Nazarevych, O.B. (2018). Innovatsiini pidkhody do vyvchennia ukrainskoi movy yak inozemnoi za dopomohoiu internet tekhnolohii [Innovative approaches to learning Ukrainian as a foreign language using Internet technologies]. IV International Scientific and Methodological Conference "Topical Issues of Organization of Study of Foreign Students in Ukraine”. May 2-4. Ternopil: TNTU [in Ukrainian]. 
9. Nazarevych, L.T., \& Havdyda, N.I. (2017). Ukrainska mova dlia inozemtsiv. Praktykum (Rivni B1-B2) [Ukrainian for foreigners. Workshop (Levels B1-B2)]. - 2nd ed.; changed and supplemented, illustrated [Tutorial]. Ternopil: FOP Palianytsia V.A. [in Ukrainian].
10. Palchykova, O.O. Problemy navchannia ukrainskoi movy $v$ inshomovniy audytorii [Problems of teaching Ukrainian in a foreign language audience]. Retrieved from: http://seanewdim.com/uploads/3/2/1/3/3213611/ palchickova_a.a._problems_of_teaching_ukrainian_in_a_ foreign_language_audience.pdf [in Ukrainian].

Received 30.01.20

Recommended 03.02.20

E-mail address for correspondence: denysiuknadia@gmail.com 